\title{
HPLC Analysis of Water-Soluble Vitamins (B2, B3, B6, B12, and $C)$ and Fat-Soluble Vitamins (E, K, D, A, and $\beta$-Carotene) of Okra (Abelmoschus esculentus)
}

\author{
Rokayya Sami, ${ }^{1,2}$ Yang Li, ${ }^{1}$ Baokun Qi, ${ }^{1}$ Shengnan Wang, ${ }^{1}$ Qiaozhi Zhang, ${ }^{1}$ Feifei Han, \\ Ying $\mathrm{Ma}^{3}{ }^{3}$ Jing Jing, ${ }^{3}$ and Lianzhou Jiang ${ }^{1}$ \\ ${ }^{1}$ Department of Food Science, Northeast Agricultural University, Harbin, Heilongjiang 150030, China \\ ${ }^{2}$ Department of Home Economics, Faculty of Education Quality, Mansoura University, Mansoura, Dakahlia 35516, Egypt \\ ${ }^{3}$ School of Food Science and Engineering, Harbin Institute of Technology, Harbin, Heilongjiang 150090, China \\ Correspondence should be addressed to Lianzhou Jiang; jlzname@163.com
}

Received 29 August 2013; Revised 11 January 2014; Accepted 17 January 2014; Published 23 February 2014

Academic Editor: Hasim Kelebek

Copyright (C) 2014 Rokayya Sami et al. This is an open access article distributed under the Creative Commons Attribution License, which permits unrestricted use, distribution, and reproduction in any medium, provided the original work is properly cited.

\begin{abstract}
Okra is consumed as a vegetable by populations in Africa and Asia and particularly in Egypt. In this study, we investigated some nutritional components of okra grown in four different geographical locations of Egypt. A comparative analysis of water-soluble vitamins (B2, B3, B6, B12, and C) and fat-soluble vitamins (E, K, D, A, and $\beta$-carotene) in okra pods was carried out. Results of principal component analysis (PCA) showed three clusters of varieties. The first cluster included the Dakahlia (D) and Kafr ElSheikh (K) varieties. The second and the third clusters separated out the Suez (S) and Mansoura (M) varieties independently. The S pod showed the highest contents of vitamins B6 $(49.81 \mu \mathrm{g} / 100 \mathrm{~g})$ and $\mathrm{E}(1.47 \mathrm{mg} / 100 \mathrm{~g})$ but contained the lowest contents of vitamins B3 $(1.42 \mu \mathrm{g} / 100 \mathrm{~g})$ and B12 (undetected). The $\mathrm{K}$ pod showed the lowest vitamin C content $(11.60 \mathrm{mg} / 100 \mathrm{~g})$. The $\mathrm{M}$ pod showed the highest contents of vitamins B3 $(22.70 \mu \mathrm{g} / 100 \mathrm{~g}), \mathrm{B} 12(91.20 \mu \mathrm{g} / 100 \mathrm{~g}), \mathrm{C}(27.14 \mathrm{mg} / 100 \mathrm{~g})$, and $\mathrm{K}(0.21 \mathrm{mg} / 100 \mathrm{~g})$. The D pod showed the lowest contents of vitamins $\mathrm{E}(0.15 \mathrm{mg} / 100 \mathrm{~g}), \mathrm{K}(0.05 \mathrm{mg} / 100 \mathrm{~g})$, and B6 $(11.50 \mu \mathrm{g} / 100 \mathrm{~g})$. These findings could help develop meal planning at the community level by incorporating okra varieties with high vitamin content.
\end{abstract}

\section{Introduction}

Cultivated okra (Abelmoschus esculentus L.), also known as "Lady's Finger" or Bamia, belongs to the Malvaceae family and is predominantly grown in the tropics and subtropics where the climates are relatively warm. Okra grows best in hot weather (temperatures above $26^{\circ} \mathrm{C}$ ), especially in regions with warm nights $\left(>20^{\circ} \mathrm{C}\right)$ [1]. In many areas, it is eaten once a week because of its high vitamin content. In general, vitamins play a very important role in maintaining health [2], contributing to a healthy immune system and providing all the nutrients essential for good health. Diets that do not contain adequate amounts of vitamins often result in vitamin deficiency-related diseases, including blindness and mental retardation, depending on the particular vitamin that is lacking. For example, nicotinamide is essential for carbohydrate metabolism and for nonredox adenosine diphosphate-ribose transfer reactions involved in DNA repair, while pyridoxine plays an essential role in amino acid transamination and riboflavin functions as a coenzyme for a wide variety of respiratory enzymes [3].

The contents of water-soluble vitamins (B-group), including thiamin, riboflavin, pyridoxine, nicotinic acid, pantothenic acid, biotin, cyanocobalamin, and folic acid, can be increased in food either in their phosphorylated forms, free forms, or attached to proteins. The numerous varieties of B vitamins available present a challenge for their detailed analysis. However, by using high-performance liquid chromatography (HPLC), 40\% higher vitamin B contents can be detected on an average than that by using classical microbiological methods [4].

Vitamin C is regarded as one of the most suitable dietetic antioxidant agents since it is naturally available in great quantities in vegetable foods $[5,6]$. Several studies have shown 
TABLE 1: Geographic locations of okra samples used for determination of vitamin contents.

\begin{tabular}{lccc}
\hline Origin & Code & Latitude & Longitude \\
\hline Dakahlia & $\mathrm{D}$ & 31.053103 & 31.580615 \\
Mansoura & $\mathrm{M}$ & 31.042536 & 31.380014 \\
Kafer El-Sheikh & $\mathrm{K}$ & 31.347304 & 30.80246 \\
Suez & $\mathrm{S}$ & 29.984721 & 32.524309 \\
\hline
\end{tabular}

the health benefits of vitamin C [7]. Fat-soluble vitamins contain phytochemicals, which are shown to have antioxidant, antibacterial, antifungal, antiviral, and anticarcinogenic properties [8]. High concentrations of antioxidants, including $\alpha$-tocopherol, are associated with a reduction in the risk of disorders related to free radical accumulation such as atherosclerosis, cancer, cataracts, and cell damage [9].

The objective of this study was to determine the vitamin contents of some okra varieties grown in Egypt in order to provide further authentic information about this important food source.

\section{Material and Methods}

2.1. Chemicals and Reagents. HPLC-grade solvents were used for analysis. Analytical reagent-grade acetonitrile and methanol were obtained from Lab-Scan (Tedia Company, USA). The water used for HPLC and sampling was prepared with a Millipore Simplicity instrument (Millipore, Molsheim, France). All vitamin standards were of chromatography grade and were purchased from Sigma Chemical Co. (Poole, Dorset).

2.2. Sample Preparation and Drying. Okra pods were collected from four different geographical locations in Egypt as follows: Suez (S pod) adjacent to the Eastern Desert, Mansoura (M pod) adjacent to the River Nile, Kafr El-Sheikh (K pod) adjacent to the Mediterranean Sea, and Dakahlia (D pod) adjacent to the Manzala Lake. Table 1 shows detailed information on the geographic location of the four Egyptian okra pods analyzed. After washing with tap water and draining, the fruits were sliced into $10 \mathrm{~mm}$ thick transverse slices using a fruit slicer. Subsequently, they were dried under direct sunlight in the dry season with an overall maximum daytime air temperature of approximately $37^{\circ} \mathrm{C}$ and a minimum night temperature of approximately $20^{\circ} \mathrm{C}$. The pods were weighed at various intervals over the entire drying period until obtaining a constant weight. The dried slices of okra were milled into a coarse powder by using a laboratory mill (D6072, Germany) and stored in polyethylene bags at room temperature.

\subsection{Determination of Water-Soluble Vitamins}

2.3.1. Okra Vitamin B Analyses. The vitamin B group was extracted according to a previously described method [10]. In brief, okra powder $(2 \mathrm{~g})$ was placed in $25 \mathrm{~mL}$ of $\mathrm{H}_{2} \mathrm{SO}_{4}$ $(0.1 \mathrm{~N})$ solution and incubated for $30 \mathrm{~min}$ at $121^{\circ} \mathrm{C}$. Then, the contents were cooled and adjusted to $\mathrm{pH} 4.5$ with $2.5 \mathrm{M}$ sodium acetate, and $50 \mathrm{mg}$ Takadiastase enzyme was added. The preparation was stored at $35^{\circ} \mathrm{C}$ overnight. The mixture was then filtered through a Whatman No. 4 filter, and the filtrate was diluted with $50 \mathrm{~mL}$ of pure water and filtered again through a micropore filter $(0.45 \mu \mathrm{m})$. Twenty microliters of the filtrate was injected into the HPLC system. Quantification of vitamin B content was accomplished by comparison to vitamin B standards. Standard stock solutions for thiamine, riboflavin, niacin, pyridoxine, and cobalamin were prepared as reported previously [11, 12]. Chromatographic separation was achieved on a reversed phase- (RP-) HPLC column (Agilent ZORBAX Eclipse Plus C18; $250 \times 4.6 \mathrm{~mm}$ i.d., $5 \mu \mathrm{m}$ ) through the isocratic delivery mobile phase (A/B 33/67; A: $\mathrm{MeOH}, \mathrm{B}: 0.023 \mathrm{M} \mathrm{H}_{3} \mathrm{PO}_{4}, \mathrm{pH}=3.54$ ) at a flow rate of $0.5 \mathrm{~mL} / \mathrm{min}$. Ultraviolet (UV) absorbance was recorded at $270 \mathrm{~nm}$ at room temperature [13].

2.3.2. Okra Ascorbic Acid Analyses. Vitamin C was extracted according to a modification of a published method [14]. The okra powder $(10 \mathrm{~g})$ was blended and homogenized with an extracting solution containing metaphosphoric acid $(0.3 \mathrm{M})$ and acetic acid $(1.4 \mathrm{M})$. The mixture was placed in a conical flask and agitated at $10,000 \mathrm{rpm}$ for $15 \mathrm{~min}$. The mixture was then filtered through a Whatman No. 4 filter, and samples were extracted in triplicate. The ascorbic acid standard was prepared by dissolving $100 \mathrm{mg}$ of L-ascorbic acid in a metaphosphoric acid $(0.3 \mathrm{M}) /$ acetic acid $(1.4 \mathrm{M})$ solution at a final concentration of $0.1 \mathrm{mg} / \mathrm{mL}$. The calibration line was converted to a linear range based on four measured concentration levels.

Quantification of ascorbic acid content was performed on an Agilent HPLC system. Chromatographic separation was achieved on an RP-HPLC column through isocratic delivery of a mobile phase (A/B 33/67; A: $0.1 \mathrm{M}$ potassium acetate, $\mathrm{pH}=4.9$, B: acetonitrile: water $[50: 50])$ at a flow rate of $1 \mathrm{~mL} / \mathrm{min}$. UV absorbance was recorded at $254 \mathrm{~nm}$ at room temperature.

\subsection{Determination of Fat-Soluble Vitamins}

2.4.1. Okra Vitamin D, E, K, A, and $\beta$-Carotene Analyses. In $10 \mathrm{~g}$ okra powder, $1 \mathrm{~g}$ of pyrogallic acid, $70 \mathrm{~mL}$ ethanol, and $30 \mathrm{~mL}(50 \%) \mathrm{KOH}$ were added, stirred, and refluxed for 40 min using a water bath at $50 \pm 2^{\circ} \mathrm{C}[15,16]$. Extracts were obtained three times using various ether concentrations $(50 \mathrm{~mL}, 30 \mathrm{~mL}$, and $20 \mathrm{~mL})$. Double-distilled water was used to neutralize the extract, which was dehydrated using anhydrous sodium sulfate. Further, the extract was concentrated to approximately $5 \mathrm{~mL}$ by using a water bath $\left(50 \pm 2^{\circ} \mathrm{C}\right)$, diluted to $10 \mathrm{~mL}$ by using methanol, filtered using a $0.45 \mu \mathrm{m}$ membrane, and finally subjected to HPLC analysis.

RP-HPLC analysis was performed with the Agilent 1100 series HPLC system (Agilent; USA), including a diode array detector. The column was made of stainless steel. For $\beta$ carotene quantification, the Agilent TC-C18 column was used $(5 \mu \mathrm{m}, 4.6 \times 250 \mathrm{~mm})$ with an acetonitrile-methyl alcoholethyl acetate $(88: 10: 2)$ solvent, and UV absorbance was recorded at $453 \mathrm{~nm}$. For fat-soluble vitamins, the Agilent Eclipse XDB-C18 column was used $(5 \mu \mathrm{m}, 4.6 \times 150 \mathrm{~mm})$, 
TABLE 2: Water-soluble vitamin contents of okra pods.

\begin{tabular}{lcccc}
\hline Varieties & S & K & M & D \\
\hline Riboflavin (vitamin B2) $(\mu \mathrm{g} / 100 \mathrm{~g}$ DW) & $\mathrm{ND}$ & $\mathrm{ND}$ & $\mathrm{ND}$ & $\mathrm{ND}$ \\
Niacin (vitamin B3) $(\mu \mathrm{g} / 100 \mathrm{~g}$ DW) & $1.42 \pm 0.42^{\mathrm{b}}$ & $7.21 \pm 0.47^{\mathrm{b}}$ & $22.70 \pm 8.69^{\mathrm{a}}$ & $7.65 \pm 0.68^{\mathrm{b}}$ \\
Pyridoxine (vitamin B6) $(\mu \mathrm{g} / 100 \mathrm{~g}$ DW) & $49.81 \pm 4.02^{\mathrm{a}}$ & $17.90 \pm 7.42^{\mathrm{c}}$ & $37.93 \pm 6.29^{\mathrm{b}}$ & $11.50 \pm 0.31^{\mathrm{c}}$ \\
Cobalamin (vitamin B12) $(\mu \mathrm{g} / 100 \mathrm{~g} \mathrm{DW})$ & $\mathrm{ND}$ & $49.56 \pm 18.55^{\mathrm{b}}$ & $91.20 \pm 20.64^{\mathrm{a}}$ & $34.54 \pm 3.69^{\mathrm{b}}$ \\
Ascorbic acid (vitamin C) $(\mathrm{mg} / 100 \mathrm{~g}$ DW) & $12.51 \pm 0.06^{\mathrm{c}}$ & $11.60 \pm 0.21^{\mathrm{c}}$ & $27.14 \pm 2.46^{\mathrm{a}}$ & $15.62 \pm 0.05^{\mathrm{b}}$ \\
\hline
\end{tabular}

Each value is presented as the mean \pm standard deviation $(n=3)$. Data with different superscript letters in the same column of variety indicate a significant difference $(P<0.05)$ as analyzed using Duncan's multiple range test. Dry weight (DW) was not detected (ND). Riboflavin (B2), niacin (B3), pyridoxine (B6), and cobalamin (B12) are expressed in $\mu \mathrm{g}$ per $100 \mathrm{~g}$. Ascorbic acid (C) is expressed in mg per $100 \mathrm{~g}$.

TABLE 3: Fat-soluble vitamin contents of okra pods.

\begin{tabular}{|c|c|c|c|c|}
\hline Varieties & $S$ & $\mathrm{~K}$ & M & $\mathrm{D}$ \\
\hline Tocopherol (vitamin E) (mg/100 g DW) & $1.47 \pm 0.06^{\mathrm{a}}$ & $0.98 \pm 0.09^{b}$ & $0.76 \pm 0.24^{\mathrm{c}}$ & $0.15 \pm 0.02^{\mathrm{d}}$ \\
\hline Menaphthone (vitamin K3) (mg/100 g DW) & $0.20 \pm 0.02^{\mathrm{a}}$ & $0.11 \pm 0.02^{\mathrm{b}}$ & $0.21 \pm 0.01^{\mathrm{c}}$ & $0.05 \pm 0.00^{\mathrm{d}}$ \\
\hline Retinol (vitamin A) ( $\mu \mathrm{g} / 100 \mathrm{~g} \mathrm{DW})$ & ND & ND & ND & ND \\
\hline Cholecalciferol (vitamin D3) ( $\mu \mathrm{g} / 100 \mathrm{~g} \mathrm{DW})$ & ND & ND & ND & ND \\
\hline$\beta$-Carotene $(\mu \mathrm{g} / 100 \mathrm{~g} \mathrm{DW})$ & ND & ND & ND & ND \\
\hline
\end{tabular}

Each value is presented as the mean \pm standard deviation $(n=3)$. Data with different superscript letters in the same column of variety indicate significant difference $(P<0.05)$ as analyzed using Duncan's multiple range test. Dry weight (DW) was not detected (ND). Tocopherol (E) and menaphthone (K3) are expressed in mg per $100 \mathrm{~g}$. Retinol (A), cholecalciferol (D3), and $\beta$-carotene are expressed in $\mu \mathrm{g}$ per $100 \mathrm{~g}$.

the solvent was methanol, and UV detection was recorded at $325 \mathrm{~nm}$ for vitamin A, $265 \mathrm{~nm}$ for vitamin D3, $290 \mathrm{~nm}$ for vitamin E, and $244 \mathrm{~nm}$ for vitamin K3. Separation of all vitamins was based on isocratic elution and the solvent flow rate was maintained at $1 \mathrm{~mL} / \mathrm{min}$. Twenty microliters of okra oil was directly injected into the HPLC column. Fatsoluble vitamins were identified by comparing their retention times with those of authentic standards. All procedures were carried out under subdued light conditions.

Standard solutions of vitamins were prepared by serial dilution to concentrations of $0.1,1,2,5$, and $10 \mathrm{mg}$ per liter of vitamins $\mathrm{D} 3, \mathrm{E}, \mathrm{K} 3, \mathrm{~A}$, and $\beta$-carotene, respectively. Standard solutions were prepared daily from a stock solution, which was stored in the dark at $-20^{\circ} \mathrm{C}$. Twenty microliters of standard solution was injected, and peak areas were determined to generate standard curves.

2.5. Statistical Analysis. Data from replications of all cultivars were subjected to analysis of variance (ANOVA) using SPSS 16.0 for Windows (SPSS Inc.; Chicago, IL, USA). The significance levels of differences between means were determined by using Duncan's new multiple range test; $P<$ 0.05 was considered statistically significant. The correlations between all studied parameters were determined by principal components analysis (PCA) using XLSTAT software.

\section{Results and Discussion}

In this study, vitamin extraction was carried out by using $0.1 \mathrm{~N} \mathrm{H}_{2} \mathrm{SO}_{4}$ and Takadiastase enzyme. Initially, hot acid hydrolysis was carried out. The enzyme was added after cooling, and the $\mathrm{pH}$ was adjusted to 4.5. Incubation at $35^{\circ} \mathrm{C}$ for over $12 \mathrm{~h}$ allowed the extraction of several vitamins simultaneously from the same sample. As previously reported, only one digestion method by using an acid and then the Takadiastase enzyme is sufficient for the detection of $B$ vitamins [17]. The separation of vitamins using HPLC with fluorometric detectors has been applied. However, compared to UV detectors, fluorometric detectors are expensive, require sophisticated procedures, and are fragile. The use of HPLC coupled with UV detection for the study of water-soluble vitamins in food has been demonstrated to be a fast, simple, and reliable method [18]. Table 2 shows the water-soluble vitamin contents (B2, B3, B6, B12, and C) for different okra pods. The vitamin $C$ content of the $S$ pod was approximately $12.51 \mathrm{mg} / 100 \mathrm{~g}$, while the $\mathrm{M}$ pod was rich in vitamin B3 $(22.70 \mu \mathrm{g} / 100 \mathrm{~g})$ and had the highest content of vitamin C $(27.14 \mathrm{mg} / 100 \mathrm{~g})$. The D pod showed the lowest content of vitamin B6 $(11.50 \mu \mathrm{g} / 100 \mathrm{~g})$ and a slightly high content of vitamin C (15.62 mg/100 g). No detectable quantities of vitamin $\mathrm{B} 2$ were observed. The $\mathrm{M}$ pod showed the highest vitamin B12 content $(91.20 \mu \mathrm{g} / 100 \mathrm{~g})$, whereas the $\mathrm{S}$ pod showed the lowest, in which no vitamin B12 was detectable. The $\mathrm{K}$ pod showed the lowest value of vitamin C $(11.60 \mathrm{mg} / 100 \mathrm{~g})$, but this value was nonetheless higher than those reported for vitamins B6, B12, and B2 $(1.20,0.13$, and $1.13 \mathrm{mg} / 100 \mathrm{~g})$ [8].

Table 3 shows important variations of the fat-soluble vitamin compositions in the studied okra samples. The $\mathrm{M}$ pod showed the highest content of vitamin K3 $(0.21 \mathrm{mg} / 100 \mathrm{~g})$, while the D pod had the lowest content $(0.05 \mathrm{mg} / 100 \mathrm{~g})$. The $\mathrm{S}$ pod had the highest vitamin $\mathrm{E}$ content $(1.47 \mathrm{mg} / 100 \mathrm{~g})$, followed by that in the $\mathrm{K}$ pod $(0.98 \mathrm{mg} / 100 \mathrm{~g})$, which was lower than the previously reported results for vitamins $\mathrm{A}, \mathrm{D}$, and $\mathrm{K}$ at $83.00,0.07$, and $1.00 \mathrm{mg} / 100 \mathrm{~g}$, respectively [8]. The other pods showed no detectable quantities of vitamin $A, \beta$ carotene, and D3.

The $\beta$-carotene content was lower than that previously reported [19] $(52.02 \mu \mathrm{g} / 100 \mathrm{~g})$. The results showed significant 


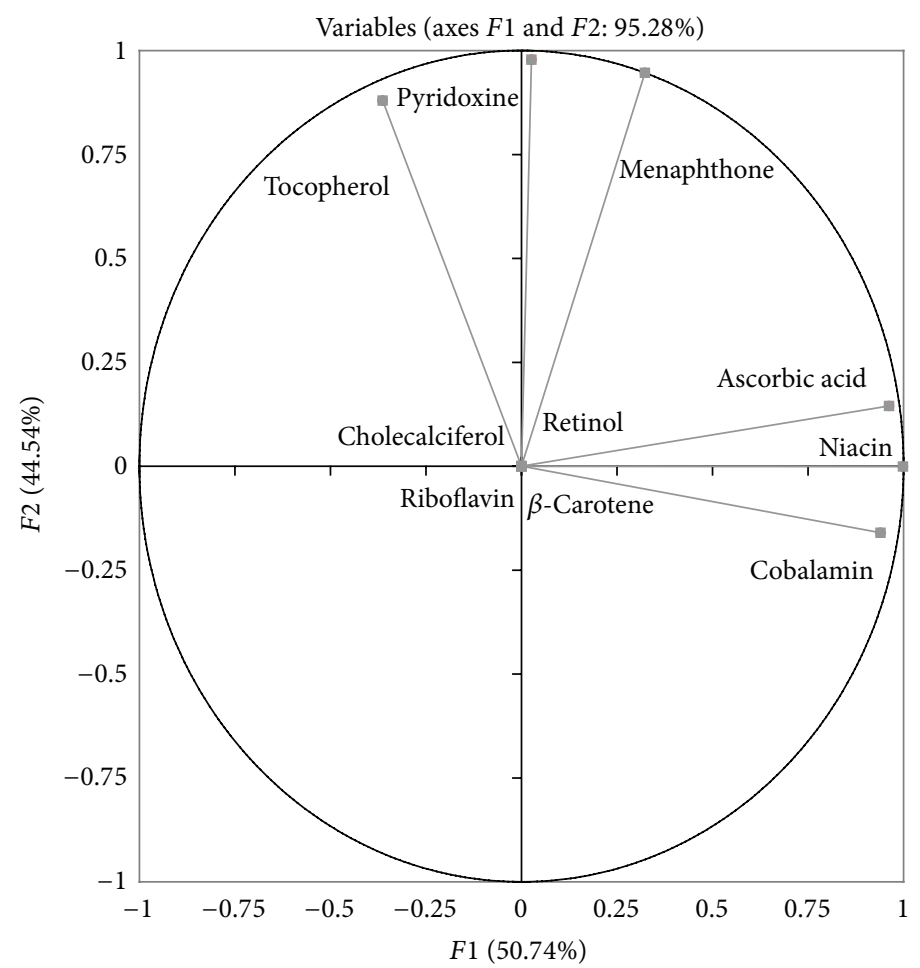

FIGURE 1: Plots of the principal component scores for vitamin contents of okra pods.

variations in the vitamin contents between the different okra varieties analyzed. Such variations can be explained by genetic factors and/or environmental factors, such as variations in soil composition among regions. The average contents of water-soluble vitamins across the different varieties were $9.75 \mu \mathrm{g} / \mathrm{g}$ for $\mathrm{B} 3,29.29 \mu \mathrm{g} / \mathrm{g}$ for vitamin B6, $43.83 \mu \mathrm{g} / \mathrm{g}$ for B12, and $16.72 \mathrm{mg} / \mathrm{g}$ for vitamin C. The average contents of fat-soluble vitamins were $0.84 \mathrm{mg} / \mathrm{g}$ for vitamin $\mathrm{E}$ and $0.14 \mathrm{mg} / \mathrm{g}$ for $\mathrm{K} 3$. Vitamins D3 and $\mathrm{A}$ and $\beta$-carotene were not detectable in any variety. These values are clearly lower than the daily requirements of vitamins for an adult (15-20 mg/day for B3, 2-3 mg/day for B6, $2.4 \mathrm{mg} /$ day for $\mathrm{B} 12,60 \mathrm{mg} /$ day for vitamin C, $8-10 \mathrm{mg} /$ day for vitamin $\mathrm{E}$, $0.08 \mathrm{mg} /$ day for D3, $2-3 \mathrm{mg} /$ day for B6, $0.8-1 \mathrm{mg} /$ day for A, 2-7 mg/day for $\beta$-carotene, and $80 \mu \mathrm{g} /$ day for $\mathrm{K} 3$ ).

3.1. Principal Component Analysis. A PCA was carried out on the vitamin content data obtained using HPLC analysis. Figures 1 and 2 present the plots of the PCA scores and correlation loadings, respectively. The score plot of PCA illustrates the large variability of the four okra varieties ( $S$, $\mathrm{M}, \mathrm{K}$, and $\mathrm{D}$ ) based on geographic location. The loadings represent the coefficients of the original variables that define each principal component [20]. The inertia percentages and variables correlated with axes PC1 and PC2 are displayed in Table 4 . The first two axes retained $95.28 \%$ of the total inertia. PC1 explained $50.74 \%$ and PC2 explained $44.54 \%$ of the inertia, which positively correlated with pyridoxine, tocopherol, and menaphthone. Plots of the scores shown in Figure 1 indicate that the data cloud was mainly bidimensional. Figure 2 shows that the varieties formed three

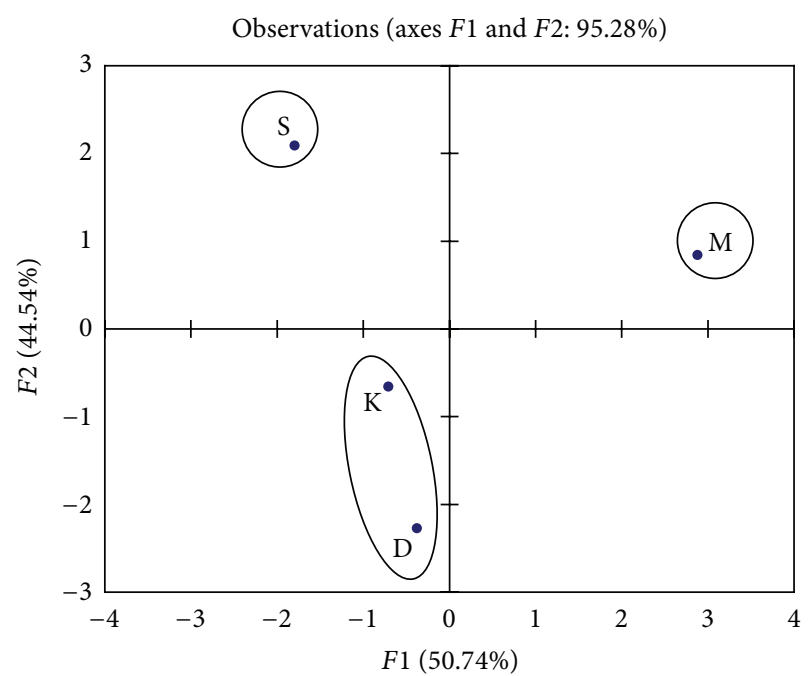

FIGURE 2: Plots of the $x$-loudings for vitamin contents of okra pods.

distinct clusters. The first cluster included the $\mathrm{D}$ and $\mathrm{K}$ varieties. The second and the third clusters separated out the $S$ and $M$ varieties independently.

\section{Conclusion}

This study focused on the quantification of okra vitamins commonly consumed in Egypt. The results were within the wide ranges of data reported in the literature. The vitamin contents of the okra varieties were significantly correlated 
TABLE 4: Discriminate factors of principal components analysis based on vitamin contents of okra pods.

\begin{tabular}{lcc}
\hline & $F 1$ & $F 2$ \\
\hline Eigenvalue & 3.04 & 2.67 \\
Variability (\%) & 50.74 & 44.54 \\
Cumulative (\%) & 50.74 & 95.28 \\
Riboflavin & - & - \\
Niacin & +32.76 & - \\
Pyridoxine & - & +35.81 \\
Cobalamin & +29.02 & - \\
Ascorbic acid & +30.42 & - \\
Tocopherol & - & +28.94 \\
Menaphthone & - & +33.5 \\
Retinol & - & - \\
Cholecalciferol & - & - \\
$\beta$-Carotene & - & - \\
\hline
\end{tabular}

with geographical origin. The S pod variety had the highest contents of vitamins $\mathrm{B} 6$ and $\mathrm{E}$ and the lowest contents of vitamins $\mathrm{B} 3$ and $\mathrm{B} 12$. The $\mathrm{K}$ pod had the lowest vitamin $\mathrm{C}$ content. The $\mathrm{M}$ pod had the highest contents of vitamins B3, $\mathrm{B} 12$, and $\mathrm{C}$, while the $\mathrm{K}$ and $\mathrm{D}$ pods had the lowest contents of vitamins $\mathrm{E}, \mathrm{K}$, and $\mathrm{B} 6$. To reduce quality loss during the drying process, some preventative measures should be taken. Some of these measures include shade drying to reduce photodegradation, slicing the vegetable into thin slices to reduce drying time, and the use of a predrying treatment, such as blanching, to reduce enzyme activities and loss of vitamins.

\section{Conflict of Interests}

The authors declare that there is no conflict of interests regarding the publication of this study.

\section{Acknowledgments}

The authors are grateful to the Harbin Institute of Technology and the Northeast Agricultural University for providing all the required facilities to carry out the present research. The authors also thank the anonymous referees for their helpful comments on the earlier draft. The present research was supported by the China Scholarship Council through a senior scholarship awarded to Rokayya Sami and by the National High-Tech R\&D Program of China (863 Program) (Research Grant no. 2013AA102104).

\section{References}

[1] J. Ndunguru and A. C. Rajabu, "Effect of okra mosaic virus disease on the above-ground morphological yield components of okra in Tanzania," Scientia Horticulturae, vol. 99, no. 3-4, pp. 225-235, 2004.

[2] C. Anyakora, I. Afolami, T. Ehianeta, and F. Onwumere, "HPLC analysis of nicotinamide, pyridoxine, riboflavin and thiamin in some selected food products in Nigeria," African Journal of Pharmacy and Pharmacology, vol. 2, pp. 029-036, 2008.

[3] W. Elfalleh, N. Nasri, N. Marzougui et al., "Physico-chemical properties and DPPH-ABTS scavenging activity of some local pomegranate (Punica granatum) ecotypes," International Journal of Food Sciences and Nutrition, vol. 60, no. 2, pp. 197-210, 2009.

[4] R. Amidžić, J. Brboric, O. Čudina, and S. Vladimirov, "RPHPLC determination of vitamins B1, B3, B6, folic acid and B12 in multivitamin tablets," Journal of the Serbian Chemical Society, vol. 70, no. 10, pp. 1229-1235, 2005.

[5] R. A. Moyer, K. E. Hummer, C. E. Finn, B. Frei, and R. E. Wrolstad, "Anthocyanins, phenolics, and antioxidant capacity in diverse small fruits: vaccinium, rubus, and ribes," Journal of Agricultural and Food Chemistry, vol. 50, no. 3, pp. 519-525, 2002.

[6] S. Sellappan, C. C. Akoh, and G. Krewer, "Phenolic compounds and antioxidant capacity of Georgia-grown blueberries and blackberries," Journal of Agricultural and Food Chemistry, vol. 50, no. 8, pp. 2432-2438, 2002.

[7] W. Okiei, M. Ogunlesi, L. Azeez, V. Obakachi, M. Osunsanmi, and G. Nkenchor, "The voltammetric and titrimetric determination of ascorbic acid levels in tropical fruit samples," International Journal of Electrochemical Science, vol. 4, no. 2, pp. 276287, 2009.

[8] C. O. Adenipekun and O. J. Oyetunji, "Nutritional values of some tropical vegetables," Journal of Applied Biosciences, vol. 35, pp. 2294-2300, 2010.

[9] F. J. Barba, M. J. Esteve, and A. Frígola, "Determination of vitamins $\mathrm{E}(\alpha-, \gamma$ - and $\delta$-tocopherol) and D (cholecalciferol and ergocalciferol) by liquid chromatography in milk, fruit juice and vegetable beverage," European Food Research and Technology, vol. 232, no. 5, pp. 829-836, 2011.

[10] AOAC International, Official Methods of Analysis, Arlington, Va, USA, 15th edition, 1990.

[11] J. Aslam, M. S. Mohajir, S. A. Khan, and A. Q. Khan, "HPLC analysis of water-soluble vitamins (B1, B2, B3, B5, B6) in in vitro and ex vitro germinated chickpea (Cicer arietinum L.)," African Journal of Biotechnology, vol. 7, no. 14, pp. 2310-2314, 2008.

[12] C. Ringling and M. Rychlik, "Analysis of seven folates in food by LC-MS/MS to improve accuracy of total folate data," European Food Research and Technology, vol. 236, pp. 17-28, 2013.

[13] N. Marzougui, F. Guasmi, M. Mkaddem et al., "Assessment of Tunisian Trigonella foenum graecum diversity using seed vitamin B6, B1, B9 and C contents," Journal of Food, Agriculture and Environment, vol. 7, no. 1, pp. 56-61, 2009.

[14] G. O. Babarinde and O. A. Fabunmi, "Effects of packing materials and storage temperature on quality of fresh okra (Abelmoschus esculentus L.) fruit," Agricultura Tropica et Subtropica, vol. 42, pp. 151-156, 2009.

[15] C. H. Jun, G. B. Zhong, L. C. Ying, L. H. Guang, Y. Q. Li, and L. R. Jun, "Study on content determination of vitamin A and $\mathrm{E}$ in white yak's milk by HPLC," Journal of Gansu Agricultural University, vol. 2, pp. 108-111, 2007.

[16] A. Aumaporn, "Effects of moisture heating and vacuum fry on organic and conventional okra quality," Asian Journal of Food and Agro-Industry, vol. 2, pp. S318-S324, 2009.

[17] S. Albalá-Hurtado, M. T. Veciana-Nogués, M. Izquierdo-Pulido, and A. Mariné-Font, "Determination of water-soluble vitamins in infant milk by high-performance liquid chromatography," Journal of Chromatography A, vol. 78, no. 1-2, pp. 247-253, 1997. 
[18] O. Heudi, T. Kilinç, and P. Fontannaz, "Separation of watersoluble vitamins by reversed-phase high performance liquid chromatography with ultra-violet detection: application to polyvitaminated premixes," Journal of Chromatography A, vol. 1070, no. 1-2, pp. 49-56, 2005.

[19] Z. D. Osunde and A. L. M. Makama, "Assessment of changes in nutritional values of locally sun-dried vegetables," AU Journal of Technology, vol. 10, pp. 248-253, 2007.

[20] W. Elfalleh, M. Ying, N. Nasri, H. Sheng-Hua, F. Guasmi, and A. Ferchichi, "Fatty acids from Tunisian and Chinese pomegranate (Punica granatum L.) seeds," International Journal of Food Sciences and Nutrition, vol. 62, no. 3, pp. 200-206, 2011. 

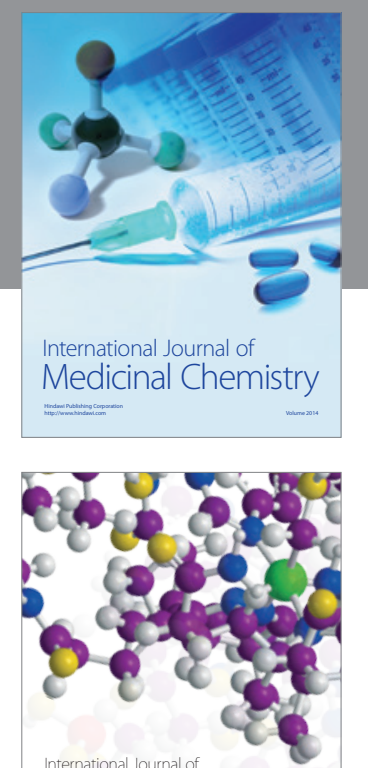

\section{Carbohydrate} Chemistry

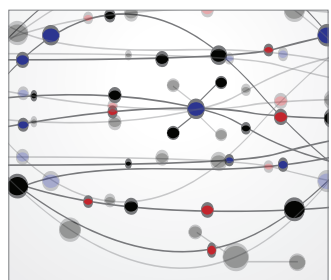

The Scientific World Journal
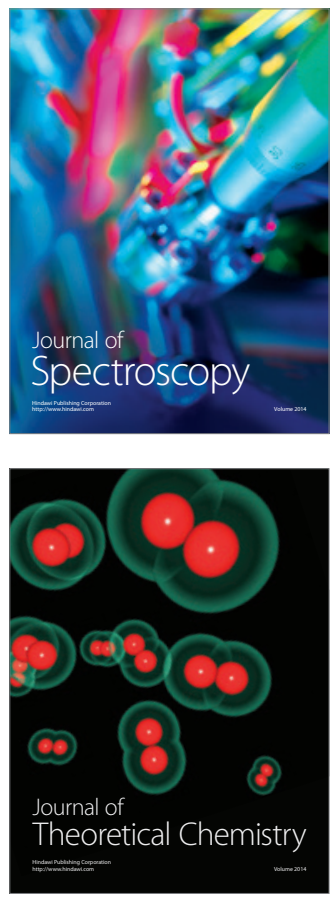
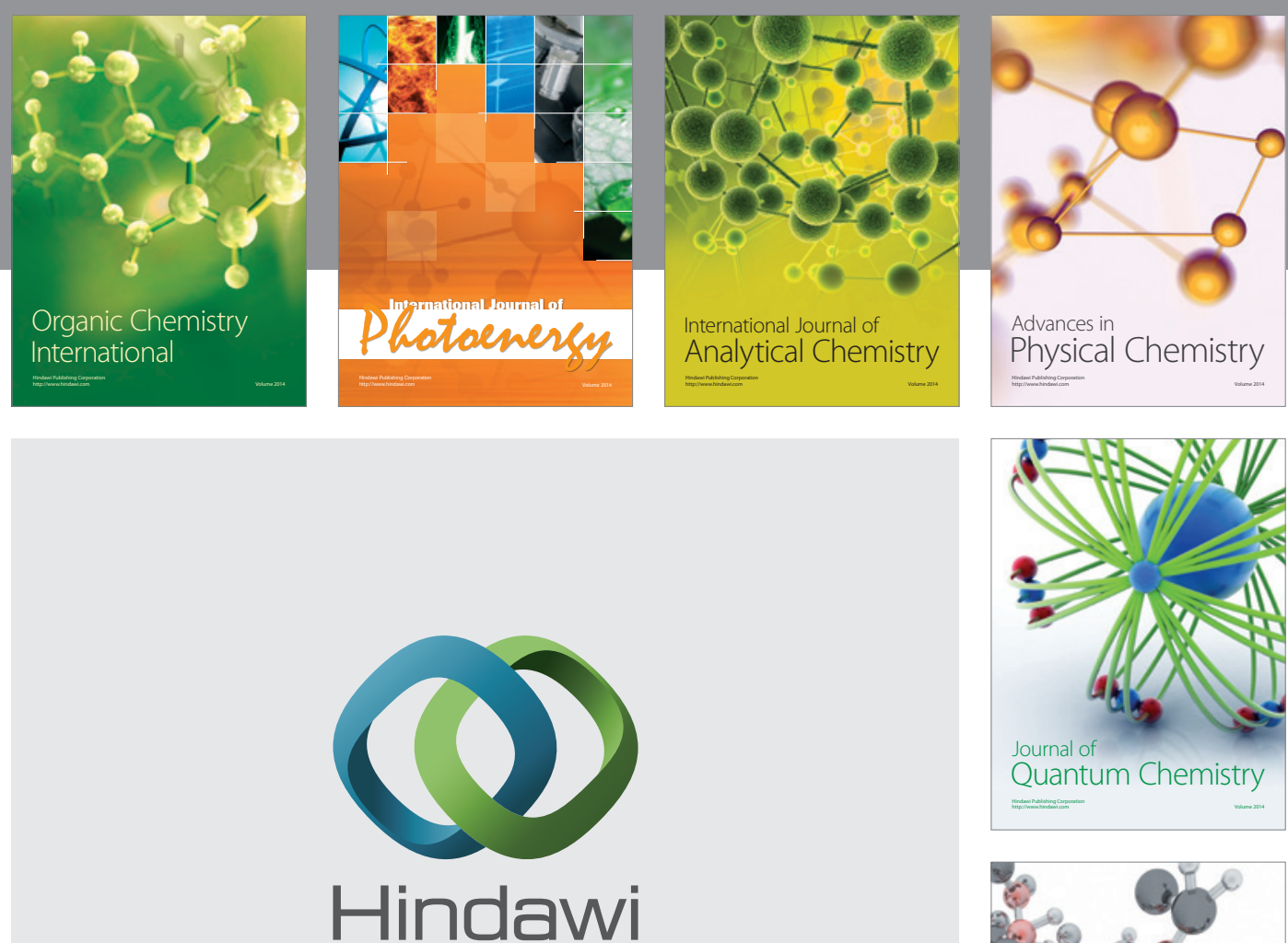

Submit your manuscripts at

http://www.hindawi.com

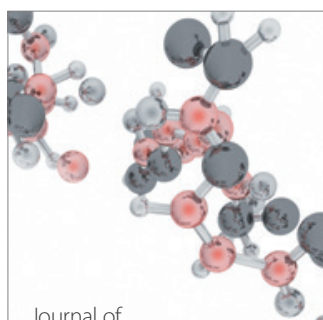

Analytical Methods

in Chemistry

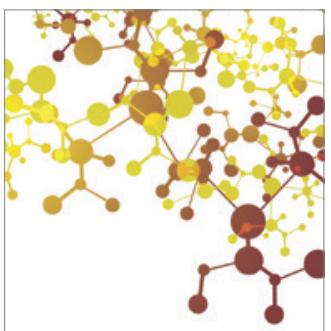

Journal of

Applied Chemistry

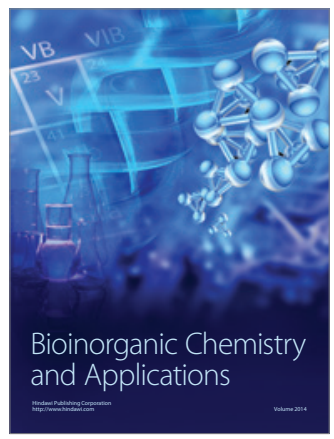

Inorganic Chemistry
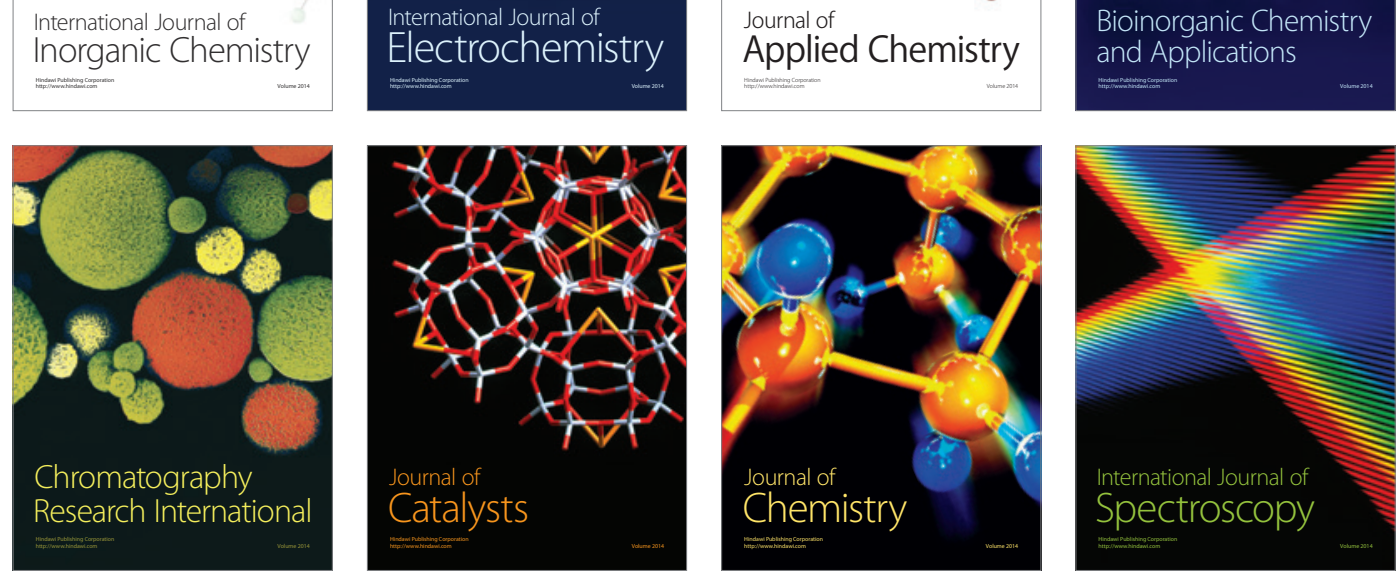